\title{
Multi-Year Evaluation of Commercial Soybean Cultivars for Resistance to Phytophthora sojae
}

\author{
T. L. Slaminko, Department of Crop Sciences, University of Illinois, Urbana 61801; C. R. Bowen, United States \\ Department of Agriculture-Agricultural Research Service (USDA-ARS), Urbana, IL 61801; and G. L. Hartman, \\ USDA-ARS and Department of Crop Sciences, University of Illinois, Urbana 61801
}

\begin{abstract}
Slaminko, T. L., Bowen, C. R., and Hartman, G. L. 2010. Multi-year evaluation of commercial soybean cultivars for resistance to Phytophthora sojae. Plant Dis. 94:368-371.

Phytophthora sojae causes damping-off, root rot, and stem rot of soybean, particularly in poorly drained soils. Soybean cultivar resistance is one of the primary methods to control this disease, with Rps 1c, Rps 1k, and Rps 1a being the most commonly used genes. The Varietal Information Program for Soybeans (VIPS) at the University of Illinois evaluates soybean cultivars for resistance to a number of diseases including Phytophthora root rot (PRR). The objectives of this research were to evaluate PRR resistance among commercial cultivars or advanced lines, and to compare these results with the information on PRR resistance provided by the company that entered the cultivar in VIPS. Each year from 2004 to 2008, between 600 and 900 cultivars were evaluated for resistance to either race 17 or 26 of $P$. sojae using the hypocotyl inoculation method. $P$. sojae single resistance genes were reported in 1,808 or $51 \%$ of the entries based on company information. Of these, the most commonly reported resistance genes were Rps 1c (50\%), Rps 1k (40\%), and Rps1a (10\%). To a much smaller degree, companies reported using Rps3a (0.3\%), Rps $1 \mathrm{~b}(0.2 \%)$, and Rps7 (0.2\%). For the duration of the 5-year testing period, almost half of the cultivars (46\%) were entered in VIPS with no reported resistance genes, and only nine out of a total of 3,533 entries (less than $0.3 \%$ ) reported a stacked combination of resistance genes. Agreement between company-reported genes and any resistance found in the VIPS PRR evaluation was highest for those cultivars claiming to have Rps 1c (90\%) and Rps $1 \mathrm{k}(83 \%)$, followed by Rps 1a (70\%). On average, 54\% of the cultivars submitted to VIPS each year were new, reflecting the rapid development and turnover of soybean cultivars provided by the soybean seed companies.
\end{abstract}

Phytophthora sojae Kaufm. \& Gerd. is a soilborne pathogen that causes Phytophthora root rot (PRR), resulting in preand postemergence damping-off, root and stem rot, yellowing and wilting of lower leaves, and death of soybean (Glycine max (L.) Merr.) plants (10). Deployment of race-specific, complete resistance genes in soybean cultivars has been the primary method used to control PRR (10). The widespread resistance provided by $R p s 1 \mathrm{k}$

Corresponding author: G. L. Hartman

E-mail: ghartman@illinois.edu

Trade and manufacturers' names are necessary to report factually on available data; however, the USDA neither guarantees nor warrants the standard of the product, and the use of the name by USDA implies no approval of the product to the exclusion of others that may also be suitable.

Accepted for publication 29 November 2009.

doi:10.1094/PDIS-94-3-0368

This article is in the public domain and not copyrightable. It may be freely reprinted with customary crediting of the source. The American Phytopathological Society, 2010. has remained effective in most soybean production areas (11), although new Rps $1 \mathrm{k}$-virulent $P$. sojae populations have been reported in some areas $(3,4,8,9,11)$.

Complete resistance is race-specific and monogenic dominant in inheritance. Eight loci condition race-specific resistance in soybean to $P$. sojae (3). Multiple alleles have been found at two of the loci, Rps 1 and Rps3, and are designated with a letter following the locus number, e.g., Rps $1 \mathrm{k}$. There is a gene-for-gene interaction between avirulence genes in $P$. sojae isolates and soybean Rps genes (5). At least 55 physiological races of $P$. sojae have been identified on the basis of compatible (susceptible) or incompatible (resistant) reactions after inoculation on a set of differential soybean lines possessing eight different Rps genes $(3,5)$.

Since 1998, publicly and privately developed soybean cultivars have been tested in Illinois through a cooperative effort by the University of Illinois Soybean Variety Testing Program and the Varietal Information Program for Soybeans (VIPS) for the agronomic and disease performance charpurpose of providing information on the acteristics of soybean cultivars (www. vipsoybeans.org). VIPS developed from the Variety Testing Program as a means to satisfy Illinois soybean producers' need to compare cultivars from multiple companies. VIPS includes evaluations of agronomic traits such as oil and protein analyses as well as disease and pest reactions, and it provides an independent, objective, and unbiased assessment of hundreds of cultivars each year. The largest production areas in the United States are predominately planted with soybean maturity groups II, III, and IV (www.ers.usda.gov), and so the data provided in VIPS have wide geographic implications.

The research presented here was conducted as part of the VIPS with specific objectives to evaluate PRR resistance among commercial cultivars or advanced lines from soybean breeding programs, and to compare these results with the company-provided information on PRR resistance. Within the VIPS set, the companyreported $P$. sojae resistance genes $R p s 1 \mathrm{c}$ (50\%), Rps1k (40\%), and Rps1a (10\%) were most frequently incorporated into soybean cultivars (www.vipsoybeans.org).

\section{MATERIALS AND METHODS}

Soybean cultivars. The soybean entries in VIPS represent cultivars or advanced breeding lines that are being considered for release as new cultivars. For the purpose of reporting in this paper, we refer to all the entries as cultivars. Between 600 and 850 cultivars were evaluated each year from 2004 to 2008 (Table 1) The list of cultivars tested each year can be found on the VIPS website, www.vipsoybeans.org. Soybean seed and specific PRR resistance information were provided by participating companies.

Race selection. Cultivars were evaluated for resistance with an isolate of race 26 of P. sojae from 2004 to 2007 and with an isolate of race 17 in 2008 . The race 17 isolate was collected from Ohio and was obtained from A. Dorrance (Ohio State University), while the race 26 isolate was isolated from St. Clair Co., IL, and was obtained from D. Malvick (9). Races 17 and 26 were selected because both are virulent in combination with Rps $1 \mathrm{~b}$, 
Rps1d, Rps3a, Rps6, and Rps7 with eight differentials. With 13 differentials, they are also reported to be virulent with $R p s 3 \mathrm{~b}$, Rps3c, Rps4, and Rps5 (10). Races 17 and 26 are not virulent on cultivars that contain $R p s 1 \mathrm{a}, R p s 1 \mathrm{c}$, and Rps $1 \mathrm{k}$, the three genes most commonly associated with resistance to $P$. sojae in commercial cultivars. Virulence patterns of the isolates were confirmed by inoculating a differential set of soybean lines (3).

Experimental design. Six seeds of each cultivar were evaluated per replication in 18-cell multi-pots that fit in a $53 \times 36 \mathrm{~cm}$ tray (Hummert International, Earth City, MO) in a soilless medium, Sunshine mix, LC1 (Sun Gro Horticulture Inc., Bellevue, WA). The cultivar Sloan, which contains no known resistance genes, was included as a susceptible check. Seventeen cultivars and the cv. Sloan were randomized within in each tray.

Inoculum preparation. The pathogen was transferred to petri dishes containing Canaday-Schmitthenner medium (CSM) 1 week prior to inoculation (11). On the day of inoculation, an inoculum slurry was prepared by cutting the agar with the pathogen into $1.5-\mathrm{cm}$ strips and passing the strips through a $60-\mathrm{ml}$ syringe until uniform. The slurry was then transferred to 10-ml syringes for application.

Plant inoculation. Seedlings were inoculated by the hypocotyl method (7) 7 days after planting by making a slit approximately $1 \mathrm{~cm}$ long in the hypocotyl below the cotyledonary node with an 18gauge needle and placing approximately $0.5 \mathrm{ml}$ of culture slurry onto the wound with the syringe. In 2004, plants were wetted with a fine spray of tap water, covered with plastic domes, and placed in a $21^{\circ} \mathrm{C}$, air-conditioned greenhouse room in $60 \%$ shade for $48 \mathrm{~h}$. In subsequent years, after inoculation, plants were set in a dew chamber $\left(100 \%\right.$ relative humidity) at $20^{\circ} \mathrm{C}$ without light for $48 \mathrm{~h}$. Plants were then placed in a greenhouse set to $24^{\circ} \mathrm{C}$ during the day and $20^{\circ} \mathrm{C}$ during the night with supplemental 1,000-watt high-pressure sodium and metal halide lighting with a 14-h photoperiod. Light intensity averaged 2.1 $\mathrm{PAR} / \mathrm{s} / \mathrm{m}^{2}$, measured using a light meter (LI-COR, Inc., Lincoln, NE). Plants were counted prior to inoculation. The number of surviving seedlings was recorded 7 days after inoculation.

Disease assessment. All cultivars were initially tested in three replications. Cultivars underwent additional testing if germination was poor. The proportion of surviving seedlings for each cultivar was calculated using data from all replications. Cultivars with 0 to $20 \%$ seedling survival were rated as susceptible. Cultivars with 80 to $100 \%$ seedling survival were considered resistant. Cultivars with more than $20 \%$ but less than $80 \%$ of the plants surviving were considered to be intermediate.

Data summary. The number and percentage of soybean cultivars tested for each company-reported $P$. sojae resistance category from 2004 to 2008 was tabulated. The expected frequencies of specific genes or absence of any genes (detectable with

Table 1. Number (and percentage) of soybean cultivars tested with race 17 or $26^{\mathrm{a}}$ of Phytophthora sojae in the University of Illinois Varietal Information Program for Soybeans and their reaction with the pathogen for each company-reported resistance category from 2004 to 2008

\begin{tabular}{|c|c|c|c|c|c|c|c|c|c|c|c|c|c|c|c|c|c|c|c|c|c|}
\hline \multirow{2}{*}{$\begin{array}{l}\text { Reported } \\
\text { resistance }\end{array}$} & \multicolumn{4}{|c|}{2004} & \multicolumn{4}{|c|}{2005} & \multicolumn{4}{|c|}{2006} & \multicolumn{4}{|c|}{2007} & \multicolumn{4}{|c|}{2008} & \multirow{2}{*}{$\begin{array}{l}\text { Tot. } \\
\text { rep }\end{array}$} \\
\hline & $\mathbf{R}^{\mathbf{b}}$ & $\mathbf{S}^{\mathbf{c}}$ & $I^{d}$ & Tot. & $\mathbf{R}$ & $\mathbf{S}$ & I & Tot. & $\mathbf{R}$ & $\mathbf{S}$ & I & Tot. & $\mathbf{R}$ & $\mathbf{S}$ & I & Tot. & $\mathbf{R}$ & $\mathbf{S}$ & I & Tot. & \\
\hline Rps 1a & $\begin{array}{c}24 \\
(86)\end{array}$ & $\begin{array}{c}4 \\
(14)\end{array}$ & 0 & 28 & $\begin{array}{c}26 \\
(63)\end{array}$ & $\begin{array}{c}15 \\
(37)\end{array}$ & 0 & 41 & $\begin{array}{c}30 \\
(63)\end{array}$ & $\begin{array}{c}14 \\
(29)\end{array}$ & $\begin{array}{c}4 \\
(8)\end{array}$ & 48 & $\begin{array}{c}17 \\
(61)\end{array}$ & $\begin{array}{c}9 \\
(32)\end{array}$ & $\begin{array}{c}2 \\
(7)\end{array}$ & 28 & $\begin{array}{c}24 \\
(77)\end{array}$ & $\begin{array}{c}6 \\
(19)\end{array}$ & $\begin{array}{c}1 \\
\text { (3) }\end{array}$ & 31 & 176 \\
\hline Rps 1b & 0 & 0 & 0 & 0 & 0 & $\begin{array}{c}1 \\
(100)\end{array}$ & 0 & 1 & 0 & 0 & $\begin{array}{c}1 \\
(100)\end{array}$ & 1 & 0 & $\begin{array}{c}1 \\
(100)\end{array}$ & 0 & 1 & 0 & 0 & 0 & 0 & 3 \\
\hline Rps 1c & $\begin{array}{l}138 \\
(86)\end{array}$ & $\begin{array}{c}22 \\
(14)\end{array}$ & $\begin{array}{c}1 \\
(1)\end{array}$ & 161 & $\begin{array}{l}150 \\
(92)\end{array}$ & $\begin{array}{l}10 \\
(6)\end{array}$ & $\begin{array}{c}4 \\
(2)\end{array}$ & 164 & $\begin{array}{l}154 \\
(93)\end{array}$ & $\begin{array}{l}10 \\
(6)\end{array}$ & $\begin{array}{c}2 \\
(1)\end{array}$ & 166 & $\begin{array}{l}159 \\
(89)\end{array}$ & $\begin{array}{l}16 \\
(9)\end{array}$ & $\begin{array}{c}3 \\
(2)\end{array}$ & 178 & $\begin{array}{l}212 \\
(91)\end{array}$ & $\begin{array}{l}16 \\
(7)\end{array}$ & $\begin{array}{c}5 \\
(2)\end{array}$ & 233 & 902 \\
\hline Rps $1 \mathrm{k}$ & $\begin{array}{l}137 \\
(85)\end{array}$ & $\begin{array}{l}18 \\
\text { (11) }\end{array}$ & $\begin{array}{l}7 \\
(4)\end{array}$ & 162 & $\begin{array}{l}148 \\
(83)\end{array}$ & $\begin{array}{c}27 \\
(15)\end{array}$ & $\begin{array}{c}3 \\
(2)\end{array}$ & 178 & $\begin{array}{l}120 \\
(82)\end{array}$ & $\begin{array}{c}24 \\
(16)\end{array}$ & $\begin{array}{c}2 \\
(1)\end{array}$ & 146 & $\begin{array}{c}90 \\
(83)\end{array}$ & $\begin{array}{c}16 \\
(15)\end{array}$ & $\begin{array}{c}3 \\
(3)\end{array}$ & 109 & $\begin{array}{l}102 \\
(84)\end{array}$ & $\begin{array}{l}15 \\
(12)\end{array}$ & $\begin{array}{c}5 \\
(4)\end{array}$ & 122 & 717 \\
\hline Rps 1c, Rps $1 \mathrm{k}$ & 0 & 0 & 0 & 0 & 0 & 0 & 0 & 0 & 0 & 0 & 0 & 0 & $\begin{array}{c}2 \\
(100)\end{array}$ & 0 & 0 & 2 & $\begin{array}{c}2 \\
(100)\end{array}$ & 0 & 0 & 2 & 4 \\
\hline Rps3a & 0 & $\begin{array}{c}1 \\
(100)\end{array}$ & 0 & 1 & 0 & $\begin{array}{c}1 \\
(100)\end{array}$ & 0 & 1 & 0 & 0 & 0 & 0 & 0 & $\begin{array}{c}1 \\
(100)\end{array}$ & 0 & 1 & $\begin{array}{c}2 \\
(67)\end{array}$ & $\begin{array}{c}1 \\
(33)\end{array}$ & 0 & 3 & 6 \\
\hline Rps $1 \mathrm{k}, R p s 6$ & 0 & 0 & $\begin{array}{c}1 \\
(100)\end{array}$ & 1 & 0 & 0 & 0 & 0 & 0 & 0 & 0 & 0 & 0 & 0 & 0 & 0 & $\begin{array}{c}1 \\
(100)\end{array}$ & 0 & 0 & 1 & 2 \\
\hline Rps $1 \mathrm{k}, R p s 7$ & 0 & 0 & 0 & 0 & $\begin{array}{c}1 \\
(100)\end{array}$ & 0 & 0 & 1 & 0 & $\begin{array}{c}1 \\
(100)\end{array}$ & 0 & 1 & $\begin{array}{c}1 \\
(100)\end{array}$ & 0 & 0 & 1 & 0 & 0 & 0 & 0 & 3 \\
\hline Rps 7 & 0 & 0 & $\begin{array}{c}1 \\
(100)\end{array}$ & 1 & $\begin{array}{c}2 \\
(67)\end{array}$ & $\begin{array}{c}1 \\
(33)\end{array}$ & 0 & 3 & 0 & 0 & 0 & 0 & 0 & 0 & 0 & 0 & 0 & 0 & 0 & 0 & 4 \\
\hline $\begin{array}{l}\text { Resistant, not } \\
\text { specified }\end{array}$ & 0 & 0 & 0 & 0 & $\begin{array}{c}5 \\
(38)\end{array}$ & $\begin{array}{c}7 \\
(54)\end{array}$ & $\begin{array}{c}1 \\
(8)\end{array}$ & 13 & $\begin{array}{c}1 \\
(100)\end{array}$ & 0 & 0 & 1 & $\begin{array}{c}1 \\
(100)\end{array}$ & 0 & 0 & 1 & 0 & 0 & 0 & 0 & 15 \\
\hline $\begin{array}{r}\text { Suspected } \\
\text { resistant }^{\mathrm{e}}\end{array}$ & 0 & 0 & 0 & 0 & 0 & 0 & 0 & 0 & 0 & 0 & 0 & 0 & $\begin{array}{c}3 \\
(50)\end{array}$ & $\begin{array}{c}3 \\
(50)\end{array}$ & 0 & 6 & $\begin{array}{c}1 \\
(17)\end{array}$ & $\begin{array}{c}4 \\
(67)\end{array}$ & $\begin{array}{c}1 \\
(17)\end{array}$ & 6 & 12 \\
\hline $\begin{array}{l}\text { Resistant, } \\
\text { all }^{\mathrm{f}}\end{array}$ & $\begin{array}{l}299 \\
(85)\end{array}$ & $\begin{array}{c}44 \\
(12)\end{array}$ & $\begin{array}{c}9 \\
(3)\end{array}$ & 352 & $\begin{array}{l}325 \\
(83)\end{array}$ & $\begin{array}{c}52 \\
(15)\end{array}$ & $\begin{array}{c}7 \\
(2)\end{array}$ & 384 & $\begin{array}{l}304 \\
(84)\end{array}$ & $\begin{array}{c}49 \\
(14)\end{array}$ & $\begin{array}{c}8 \\
(2)\end{array}$ & 361 & $\begin{array}{l}269 \\
(84)\end{array}$ & $\begin{array}{c}41 \\
(14)\end{array}$ & $\begin{array}{c}8 \\
(2)\end{array}$ & 318 & $\begin{array}{l}341 \\
(87)\end{array}$ & $\begin{array}{c}37 \\
(10)\end{array}$ & $\begin{array}{l}11 \\
(3)\end{array}$ & 389 & 1804 \\
\hline Segregating & 0 & $\begin{array}{c}1 \\
(100)\end{array}$ & 0 & 1 & 0 & $\begin{array}{c}1 \\
(100)\end{array}$ & 0 & 1 & 0 & 0 & 0 & 0 & 0 & 0 & 0 & 0 & 0 & 0 & 0 & 0 & 2 \\
\hline Seg. Rps 1c & 0 & 0 & $\begin{array}{c}2 \\
(100)\end{array}$ & 2 & $\begin{array}{c}2 \\
(50)\end{array}$ & $\begin{array}{c}2 \\
(50)\end{array}$ & 0 & 4 & $\begin{array}{c}2 \\
(67)\end{array}$ & $\begin{array}{c}1 \\
(33)\end{array}$ & 0 & 3 & 0 & 0 & 0 & 0 & 0 & 0 & $\begin{array}{c}1 \\
(100)\end{array}$ & 1 & 10 \\
\hline Seg. Rps $1 \mathrm{k}$ & $\begin{array}{c}3 \\
(23)\end{array}$ & $\begin{array}{c}10 \\
(77)\end{array}$ & 0 & 13 & $\begin{array}{c}5 \\
(29)\end{array}$ & $\begin{array}{c}8 \\
(47)\end{array}$ & $\begin{array}{c}4 \\
(24)\end{array}$ & 17 & $\begin{array}{c}2 \\
(22)\end{array}$ & $\begin{array}{c}6 \\
(67)\end{array}$ & $\begin{array}{c}1 \\
(11)\end{array}$ & 9 & 0 & 0 & 0 & 0 & 0 & 0 & $\begin{array}{c}1 \\
(100)\end{array}$ & 1 & 40 \\
\hline $\begin{array}{l}\text { Segregating, } \\
\text { all }\end{array}$ & $\begin{array}{c}3 \\
(19)\end{array}$ & $\begin{array}{c}11 \\
(69)\end{array}$ & $\begin{array}{c}2 \\
(12)\end{array}$ & 16 & $\begin{array}{c}7 \\
(32)\end{array}$ & $\begin{array}{c}11 \\
(50)\end{array}$ & $\begin{array}{c}4 \\
(18)\end{array}$ & 22 & $\begin{array}{c}4 \\
(33)\end{array}$ & $\begin{array}{c}7 \\
(58)\end{array}$ & $\begin{array}{c}1 \\
(8)\end{array}$ & 12 & 0 & 0 & 0 & 0 & 0 & 0 & $\begin{array}{c}2 \\
(100)\end{array}$ & 2 & 52 \\
\hline No gene & $\begin{array}{l}179 \\
(37)\end{array}$ & $\begin{array}{l}274 \\
(57)\end{array}$ & $\begin{array}{l}25 \\
(5)\end{array}$ & 478 & $\begin{array}{l}106 \\
(30)\end{array}$ & $\begin{array}{l}237 \\
(66)\end{array}$ & $\begin{array}{l}15 \\
(4)\end{array}$ & 358 & $\begin{array}{l}73 \\
\text { (23) }\end{array}$ & $\begin{array}{l}221 \\
(71)\end{array}$ & $\begin{array}{l}17 \\
(5)\end{array}$ & 311 & $\begin{array}{c}77 \\
(28)\end{array}$ & $\begin{array}{l}182 \\
(67)\end{array}$ & $\begin{array}{l}13 \\
(5)\end{array}$ & 272 & $\begin{array}{c}40 \\
(18)\end{array}$ & $\begin{array}{l}159 \\
(73)\end{array}$ & $\begin{array}{l}19 \\
(9)\end{array}$ & 218 & 1637 \\
\hline Total & $\begin{array}{l}481 \\
(57)\end{array}$ & $\begin{array}{l}330 \\
(39)\end{array}$ & $\begin{array}{l}37 \\
(4)\end{array}$ & 848 & $\begin{array}{l}445 \\
(57)\end{array}$ & $\begin{array}{l}310 \\
(40)\end{array}$ & $\begin{array}{l}27 \\
(3)\end{array}$ & 782 & $\begin{array}{l}382 \\
(56)\end{array}$ & $\begin{array}{l}277 \\
(40)\end{array}$ & $\begin{array}{l}27 \\
(4)\end{array}$ & 686 & $\begin{array}{l}350 \\
(58)\end{array}$ & $\begin{array}{l}228 \\
(38)\end{array}$ & $\begin{array}{l}21 \\
(4)\end{array}$ & 599 & $\begin{array}{l}384 \\
(62)\end{array}$ & $\begin{array}{l}201 \\
(33)\end{array}$ & $\begin{array}{l}33 \\
(5)\end{array}$ & 618 & 3533 \\
\hline
\end{tabular}

\footnotetext{
a Race 26 was used from 2004 to 2007. Race 17 was used in 2008. Both races are not virulent on cultivars that contain Rps1a, Rps1c, and Rps1k.

b $\mathrm{R}=$ Resistant with greater than $80 \%$ of seedlings surviving 7 days after inoculation.

c S $=$ Susceptible with less than $20 \%$ of seedlings surviving 7 days after inoculation.

d I = Intermediate/segregating with 20 to $80 \%$ of seedlings surviving 7 days after inoculation.

${ }^{\mathrm{e}}$ Cultivars were entered as resistant by the company if resistance was suspected but no evaluations had been conducted.

f Includes all reported single resistance genes except for $R p s 1 \mathrm{~b}, \operatorname{Rps} 3 \mathrm{a}$, or $\operatorname{Rps} 7$, which cannot be detected using race 17 or 26.
} 
race 17 or 26) were calculated by chisquare using data from all years. This was compared to the actual frequency of a reported gene each year. For the absence of any gene, all susceptible cultivars were included, regardless of their companyreported information. To predict the proportion of cultivars remaining in VIPS after their first year of being tested, a logistic model was constructed (SAS Institute, Cary, NC).

\section{RESULTS}

More than 3,500 entries were screened for resistance to PRR as part of the VIPS screening program from 2004 to 2008 (Table 1). Single resistance genes were reported in 1,808 entries $(51 \%)$. Of these, the most commonly reported genes were Rps1c (50\%), Rps 1k (40\%), and Rps1a $(10 \%)$. Reported to a much smaller degree were Rps3a $(0.3 \%)$, Rps $1 \mathrm{~b}(0.2 \%)$, and Rps7 (0.2\%). For the duration of the 5-year testing period, almost half of the cultivars $(46 \%)$ had no reported resistance genes, and only nine out of a total of 3,533 entries (less than $0.3 \%$ ) were reported to contain a combination of resistance genes.

We observed a resistant reaction most frequently for cultivars purported to contain Rps1c (90\%) and Rps1k (83\%), followed by Rps1a (70\%) (Table 1). Results from the VIPS testing confirmed PRR resistance in soybean cultivars reported by the companies from 83 to $87 \%$ of the time over a 5-year period. Consistency was lower for cultivars reported to be segregating or for those without a reported resistance gene. An intermediate response was rare for cultivars with reported resistance genes but not uncommon in cultivars with no reported genes. Cultivars reported to be segregating for a gene were more often susceptible than segregating or resistant. Cultivars reported to have no resistance gene were susceptible in $67 \%$ of the cases. Surprisingly, $27 \%$ of cultivars with no gene reported were resistant to the isolates used in the VIPS evaluations, while the remaining $6 \%$ had an intermediate response. From 2004 to 2008, the number of cultivars in VIPS with no reported resistance decreased, and in 2008 , only $18 \%$ of the cultivars that were reported by companies to have no PRR resistance genes were resistant to race 17 . This decreased from $37 \%$ of cultivars with no reported gene that were resistant to our isolate of $P$. sojae in 2004. The frequency of genes reported by the seed providers changed over time (Table 2). Chi-square analysis indicated that the reported prevalence of Rps 1c significantly increased, from $19 \%$ in 2004 to $26 \%$ in 2008 , while cultivars with no re-

Table 2. Percentage of soybean cultivars in each Phytophthora sojae resistance category reported by company information for the Varietal Information Program for Soybeans from 2004 to 2008

\begin{tabular}{|c|c|c|c|c|c|c|}
\hline Reported resistance & 2004 & 2005 & 2006 & 2007 & 2008 & Mean \\
\hline Rps 1a & 3 & 5 & 7 & 5 & 5 & 5 \\
\hline Rps $1 \mathrm{~b}$ & 0 & $0^{\mathrm{a}}$ & $0^{\mathrm{a}}$ & $0^{\mathrm{a}}$ & 0 & $0^{\mathrm{a}}$ \\
\hline Rps $1 \mathrm{c}$ & 19 & 21 & 24 & 30 & 38 & 26 \\
\hline Rps $1 \mathrm{k}$ & 19 & 23 & 21 & 18 & 20 & 20 \\
\hline Rps $1 \mathrm{c}, R p s 1 \mathrm{k}$ & 0 & 0 & 0 & $0^{\mathrm{a}}$ & $0^{\mathrm{a}}$ & $0^{\mathrm{a}}$ \\
\hline Rps3a & $0^{\mathrm{a}}$ & $0^{\mathrm{a}}$ & 0 & $0^{\mathrm{a}}$ & $0^{\mathrm{a}}$ & $0^{\mathrm{a}}$ \\
\hline Rps $1 \mathrm{k}, R p s 6$ & $0^{\mathrm{a}}$ & 0 & 0 & 0 & $0^{\mathrm{a}}$ & $0^{\mathrm{a}}$ \\
\hline Rps $1 \mathrm{k}, R p s 7$ & 0 & $0^{\mathrm{a}}$ & $0^{\mathrm{a}}$ & $0^{\mathrm{a}}$ & 0 & $0^{\mathrm{a}}$ \\
\hline Rps 7 & $0^{\mathrm{a}}$ & $0^{\mathrm{a}}$ & 0 & 0 & 0 & $0^{\mathrm{a}}$ \\
\hline Resistant $^{\mathrm{b}}$ & 0 & 2 & $0^{\mathrm{a}}$ & $0^{\mathrm{a}}$ & 0 & $0^{\mathrm{a}}$ \\
\hline Suspected resistant ${ }^{\mathrm{c}}$ & 0 & 0 & 0 & 1 & 1 & $0^{\mathrm{a}}$ \\
\hline Segregating & $0^{\mathrm{a}}$ & $0^{\mathrm{a}}$ & 0 & 0 & 0 & $0^{\mathrm{a}}$ \\
\hline Seg. Rps $1 \mathrm{c}$ & $0^{\mathrm{a}}$ & 1 & $0^{\mathrm{a}}$ & 0 & $0^{\mathrm{a}}$ & $0^{\mathrm{a}}$ \\
\hline Seg. Rps $1 \mathrm{k}$ & 2 & 2 & 1 & 0 & $0^{\mathrm{a}}$ & 1 \\
\hline No gene & 56 & 46 & 45 & 45 & 35 & 46 \\
\hline
\end{tabular}

a Percentage is greater than 0 but less than 0.5 .

${ }^{\mathrm{b}}$ Cultivars were entered into VIPS as R (resistant) if cultivars were thought to have resistance to $P$. sojae but the specific gene was unknown.

${ }^{\mathrm{c}}$ Cultivars were entered as resistant if resistance was suspected but no evaluations had been conducted.

Table 3. Number, proportion, and predicted proportion of soybean cultivars reevaluated each year for resistance to Phytophthora sojae in the Varietal Information Program for Soybeans from 2004 to 2008

\begin{tabular}{|c|c|c|c|c|c|}
\hline \multirow[b]{2}{*}{ Year } & \multicolumn{5}{|c|}{ Number of years in trial } \\
\hline & 1 & 2 & 3 & 4 & 5 \\
\hline 2004 & $855(1.0)$ & $388(0.45)$ & $221(0.26)$ & $88(0.10)$ & $38(0.04)$ \\
\hline 2005 & $782(1.0)$ & $356(0.46)$ & $149(0.19)$ & $71(0.09)$ & \\
\hline 2006 & $688(1.0)$ & $257(0.37)$ & $125(0.18)$ & & \\
\hline 2007 & $602(1.0)$ & $270(0.45)$ & & & \\
\hline 2008 & $618(1.0)$ & & & & \\
\hline Average & & 0.44 & 0.21 & 0.1 & 0.05 \\
\hline Predicted $\left(\mathrm{CI}^{\mathrm{a}}\right)$ & & 0.43 & 0.22 & 0.1 & 0.03 \\
\hline & & $(0.42-0.45)$ & $(0.21-0.23)$ & $(0.09-0.11)$ & $(0.03-0.05)$ \\
\hline
\end{tabular}

${ }^{\mathrm{a}}$ Confidence interval $(P<0.05)$. ported resistance significantly decreased. The number of cultivars reported with Rps 1a and Rps1k was not found to significantly differ over the years of the trials.

On average, $46 \%$ of the cultivars tested in VIPS in a given year were resubmitted in the subsequent year (Table 3). About $4 \%$ of the lines initially tested in 2004 remained in the program in 2008. The proportion of soybean cultivars reevaluated each year decreased at a similar rate each year regardless of the year they were first entered into VIPS.

\section{DISCUSSION}

VIPS provides an independent, objective, and unbiased assessment of hundreds of soybean cultivars used or targeted for use in the majority of soybean acreage in the United States. The accuracy of PRR resistance reports from companies improved over time, probably because of increased company testing for resistance to $P$. sojae, as well as better classification by and communication from participating companies. Companies benefit from our information because VIPS screenings identify the presence of resistance genes that were not reported in their cultivars.

Results from the VIPS trials did not agree with company-reported resistance to PRR $15 \%$ of the time. Variability among isolates and techniques and/or environmental conditions, as well as loss of pathogen virulence with long-term culture, may have caused response differences. Also, companies often have limited seed available for identifying genes for resistance to PRR, or in some cases, companies may purchase or license cultivars to sell without verifying PRR resistance. In an effort to provide producers with information about new cultivars, originators may employ alternative techniques to assign $P$. sojae resistance genes such as the use of molecular markers, evaluating seed from earlier and perhaps segregating generations, relying on field observations, or assigning genes based on parent genotypes. Additionally, commercial cultivars may have varying levels of tolerance or partial resistance instead of or in addition to specific resistance genes that cannot be detected by the hypocotyl inoculation technique (6).

When companies submit seed to VIPS, they may comment on the type of PRR resistance with designations such as "resistant," "resistance suspected," "segregating," "segregating for Rps 1c," "segregating for Rps1k," or "no gene." In 2005 more than any other year, a number of cultivars were entered simply as "resistant," without specific mention of a gene. These were not found to be resistant, indicating a lack of the most commonly deployed genes (Rps1c, Rps 1k, and Rps 1a). In 2007 and 2008, some cultivars were entered for the first time as "resistance suspected," and only a third of these were found to be re- 
sistant. It is possible that if the resistance status to PRR was not known, companies entered cultivars as "resistant" or "resistance suspected" instead of "no gene." From 2004 to 2006, companies described a number of cultivars' reactions to PRR as segregating, either with or without the mention of a specific gene. Of the 52 lines designated as such, 29 (56\%) were susceptible, $14(27 \%)$ were resistant, and only 8 $(15 \%)$ had an intermediate response that would support a segregation assertion by the company. It is again possible that these options were used if resistance was unknown, perhaps if resistance genes were present in a cultivar's progenitors.

An intermediate reaction was observed in $4 \%$ of the VIPS entries, most commonly in entries that had no reported $P$. sojae resistance genes. There are several possible explanations for this type of response. One is that entries were segregating for the presence or absence of a resistance gene, which could be the case if $P$. sojae resistance was not a consideration and was not tested in the breeding process. Another possibility is that the seed lot was a mixture of different genetics, due to an intentional mixture, contamination during seed production, or the result of a bulk increase from an early generation selection in the breeding process.

Of the reported single resistance genes in the VIPS trials for the last 5 years, the most commonly mentioned were Rps $1 \mathrm{c}$ and $R p s 1 \mathrm{k}$, followed by Rps $1 \mathrm{a}$. In a study of $P$. sojae isolates from Indiana fields from 1996 to 2000, approximately 81, 60, and $60 \%$ of counties were found to contain isolates virulent in combination with Rps1a, Rps1c, and Rps1k, respectively (2). From samples collected in 1997 and 1999 from Ohio fields in 21 counties, approximately 96,73 , and $78 \%$ of the 86 locations sampled were found to be virulent with $R p s 1 \mathrm{a}, R p s 1 \mathrm{c}$, and $R p s 1 \mathrm{k}$, respectively (4). In Illinois farm fields in 2001 and 2002, the virulence patterns for 121 isolates from 32 counties were determined. Approximately 64,42 , and $36 \%$ of isolates were virulent with $R p s 1 \mathrm{a}, R p s 1 \mathrm{c}$, and $R p s 1 \mathrm{k}$, respectively (9).
Only six cultivars $(0.2 \%)$ were reported to have Rps3a from 2004 to 2008. In the most recent studies from Indiana (2), Ohio (4), and Illinois (9), 19, 51, and 6\% of locations or isolates tested were virulent in combination with Rps3a, respectively. In those same studies, 68, 52, and 9\%, respectively, were virulent with Rps6. Novel gene introduction is an effective strategy for management since many races of the pathogen in an area may not overcome the new genes. In Illinois, Rps3a and Rps6 might be more effective in reducing disease than the more commonly deployed genes. Another candidate gene for introduction is $R p s 8$, which was newly reported in 2003 (1)

Gene stacking is another option for soybean cultivar development that may provide effective resistance to multiple races of $P$. sojae. Only nine cultivars in the 5 years of testing were reported to contain more than one resistance gene. Gene stacking may be particularly useful if less common genes, such as Rps3a and Rps8, are used in combination with more common genes, like Rps1c. The effort required to incorporate and detect multiple, stacked resistance genes is higher than that for singly incorporated genes. Additionally, the cost to incorporate a less commonly used gene that may not already be in elite breeding lines is higher because it requires utilizing older cultivars or accessions, perhaps not fully adapted for commercial use in a specific area.

Soybean cultivars in VIPS are entered by seed companies and Illinois soybean growers for evaluation and comparison with other cultivars and thus may not exactly reflect the cultivars planted in the state or in the regions of the United States where maturity groups II, III, and IV are normally planted. However, the VIPS entry list does provide an annual representation of cultivars of interest and shows that most of the commercial soybean cultivars have a short product life. Less than $25 \%$ of cultivars remained in the program for 3 years, and less than $5 \%$ remained after 4 years. This relatively short product life makes a program like VIPS even more important, as it provides growers with timely, independently obtained information, including PRR resistance, on soybean cultivars that they may choose to grow.

\section{ACKNOWLEDGMENTS}

We thank the Illinois Soybean Association for support of this research through funding of VIPS, the University of Illinois Soybean Variety Testing Program. We also thank E. Grunden and D. Malvick for technical assistance, and T. Herman for editorial review.

\section{LITERATURE CITED}

1. Burnham, K. D., Dorrance, A. E., Francis, D M., Fioritto, R. J., and Martin, S. K. S. 2003 $R p s 8$, a new locus in soybean for resistance to Phytophthora sojae. Crop Sci. 43:101-105.

2. Cochran, A. J. 2001. Population dynamics of Phytophthora sojae in Indiana and the influence on management practices on the pathogen. Ph.D. diss. Purdue University, Lafayette, IN.

3. Dorrance, A. E., Jia, H., and Abney, T. S. 2004. Evaluation of soybean differentials for their interaction with Phytophthora sojae. Plant Health Progress doi:10.1094/PHP-2004-030901-RS.

4. Dorrance, A. E., McClure, S. A., and deSilva, A. 2003. Pathogenic diversity of Phytophthord sojae in Ohio soybean fields. Plant Dis. 87:139-146.

5. Dorrance, A. E., and Schmitthenner, A. F. 2000. New sources of resistance to Phytophthora sojae in the soybean plant introductions. Plant Dis. 84:1303-1308.

6. Ferro, C. R., Hill, C. B., Miles, M. R., and Hartman, G. L. 2006. Evaluation of soybean cultivars with Rpslk gene for partial resistance or field tolerance to Phytophthora sojae. Crop Sci. 46:2427-2436.

7. Haas, J. H., and Buzzell, R. I. 1976. New races 5 and 6 of Phytophthora megasperma var. sojae and differential reactions of soybean cultivars for races 1 to 6 . Phytopathology 66:1361-1362.

8. Leitz, R. A., Hartman, G. L., Pedersen, W. L., and Nickell, C. D. 2000. Races of Phytophthora sojae on soybean in Illinois. Plant Dis. 84:487.

9. Malvick, D. K., and Grunden, E. 2004. Traits of soybean-infecting Phytophthora populations from Illinois agricultural fields. Plant Dis. 88:1139-1145.

10. Schmitthenner, A. F. 1999. Phytophthora root rot. Pages 39-42 in: Compendium of Soybean Diseases, 4th ed. G. L. Hartman, J. B. Sinclair, and J. C. Rupe, eds. American Phytopathological Society, St. Paul, MN.

11. Schmitthenner, A. F., Hobe, M., and Bhat, R. G. 1994. Phytophthora sojae races in Ohio over a 10-year interval. Plant Dis. 78:269-276. 